EESTI NSV TEADUSTE AKADEEMIA TOIMETISED. V KÖIDE BIOLOOGILINE SEERIA 1956, $\mathrm{nr}, 2$

ИЗВЕСТИЯ АКАДЕМИИ НАУК ЭСТОНСКОЙ ССР. ТОМ V СЕРИЯ БИОЛОГИЧЕСКАЯ. 1956, N․-2

\title{
МИКРОБИОЛОГИЧЕСКИЕ ПРОЦЕССЫ В ПОЧВАХ КУЛЬТУРНЫХ ПАСТБИЩ И АКТИВИЗАЦИЯ ИХ ПРИ ВНЕСЕНИИ ОРГАНИЧЕСКИХ УДОБРЕНИЙ
}

\author{
Т. А. ВИНОГРАДОВА, \\ кандидат сельскохозяйственных наук
}

\begin{abstract}
Для Эстонской ССР, в которой животноводство в силу природных, исторических и экономических условий 'является одной из основных отраслей сельского хозяйства, проблема летнего кормления скота стоит очень остро. Естественныє пастбиша занимают в республике свыше одной трети сельскохозяйственных земель, но они дают очень низкие урожаи, не превышающие 300-400 кормовых единиц с 1 га и не могут удовлетворить потребности крупных животноводческих хозяйств.

Проблема летнєго кормления скота в условиях Эстонии может быть наиболее успешно решена путем создания долголетних культурных пастбищ, высокая эффективность которых доказана как опытом научно-исследовательских учреждений, так и практикой колхозов и совхозов республики.

Большое-экономическое значение долголєтних культурных пастбищ в дєле подъема животноводства в настоящее время не вызывает сомнений. В решениях XX съезда КПСС указывается на необходимость проведения в Прибалтийских республиках в широких масштабах работ по улучшению лугов и созданию культурных долголетних пастбищ. Однако до последнего времени широкое внедрение культурных пастбищ задерживалось существовавшим мнением, будто введение их не соответствует требованиям крупного социалистического сельского хозяйства и противоречит учению В. Р. Вильямса о травопольной системе земледелия. Существовало мнение, что на долголєтних пастбищах неизбежно происходит дерновый процесс, приводящий к вырождению травостоя.

Деградацию травостоя при долголетнем использовании В. Р. Вильямс объяснял, как известно, накоплением органического вещества в почве луга, затуханием микробиологической деятельности, а вследствиє этого, отсутствием необходимого количества минеральных веществ для питания растений.

В действительности же, как показала практика использования культурных пастбищ в Прибалтийских советских республиках и за границей, при условии правильного подбора видов трав, правильной загонной пастьбы и систематическом удобрєнии, урожаи в течение десятилетий остаются на высоком уровне.
\end{abstract}


Важное значение в поддержании высокой продуктивности культурных пастбищ в течение длительного времени имеет регулярное внесение наряду с минеральными также и органических удобрений (Тоомре, 1955).

Әффективность органических удобрений на культурных пастбищах весьма-значительна. На фоне органических удобрений увеличивается действие вносимых минеральных удобрений, что объясняется повышением биогенности почв пастбищ.

Знание происходящих в почве микробиологических процессов, которые в большой степени определяют плодородие почвы, может иметь важное значение в решении вопросов рационального применения удобрений на культурных пастбищах с целью максимального повышения их продуктивности.

Мєжду тем исследований условий распада и синтеза органических веществ в почвах лугов и пастбищ очень мало, а работы, посвященные специальному изучению микробиологических процессов, лежащих в основе превращений питательных веществ в этих почвах, почти отсутствуют. Мало изучены также вопросы влияния различных приемов удобрения и использования пастбищ на развитие микробиологичєских процессов в их почвах.

Целью настоящей работы было изучение микробиологических процессов в почвах культурных пастбищ в сравнении с почвой сенокоса и поля, чтобы выяснить биологические причины различий, наблюдающихся в ходе дернового процесса на сенокосе и пастбище. Исслєдовались пастбища на разных типах почв, при различной длительности использования и при разных условиях удобрения.

Вторая задача проведенных исследований заключалась в изучении роли органических удобрений в повышении продуктивности культурных пастбищ на различных типах почв Эстонии с одновременным изучениєм влияния органических удобрений на развитие микрофлоры этих почв.

Была сделана попытка повысить биологическую активность вносимых торфонавозных компостов путем заражения их азотобактером.

\section{Сравнительная характеристика микрофлоры почв культурного пастбища, луга и поля}

Изучение микрофлоры почвы культурного пастбища в сравнении с микрофлорой луга и поля проводилась в двух пунктах: на Йыгеваской государственной селекционной станции и в Куузикуском филиале Института растениеводства Академии наук Әстонской ССР.

В Куузику был исследован состав микрофлоры в почвах культурного пастбища, заложенного в 1947 году способом коренного улучшения (пастьба начата с 1951 года), естественного сенокоса, где дерновый процесс привел к вырождению травостоя, и высокоплодородного полевого участка (широкорядный посев многолетних трав первого года жизни), расположенных на одной и той же разности почв. Почва исследованных участков супесчаная, слабо подзолистая, дерново-глеевая на карбонатных супесях. Кроме того, в Куузику на молодом пастбище, в опыте заложенном Институтом растениеводства Академии наук ЭССР в 1952 году (посев 1949 года), проводилось сравнительное изучєние динамики развития основных групп микроорганизмов в почве культурного пастбища и культурного луга при одинаковой системе удобрения.

В Йгева изучалась микрофлора культурного сенокоса и культурного пастбища, заложенных в 1925 году на раскорчеванном из-под леса участке путем поверхностной обработки, удобрения и посева многолетних трав. До 1951 года оба участка использовались как сенокос, а с 1951 го- 
да на одной части луга началась загонная пастьба. Таким образом, история закладки, удобрениє и почва исследованных участков были одинаковыми, различным был с 1951 года только характер использования. Наряду с этим в Иыгева изучались микробиологические процессы в почве культурного пастбища 33-летней длительности использования (пастбище заложено в 1921 году на поле многолетних трав), а также близлежащего участка полевого севооборота с селєкционными посевами льна. Почва первых двух участков дерново-глееватая суглинистая с богатым содержанием гумуса (до $15 \%$ ) в перегнойном горизонте, почва других - дерново-слабо-подзолистая (гумуса около 6\%).

Пастбищное использование оказало большое влияние на состав травостоя не только на тех участках, которые в тєчение длительного времени использовались в качестве пастбищ, но также и на сравнительно молодых. Травостой куліьтурных пастбищ отличается от сенокосного бо́льшей густотой, преобладанием низовых злаков и белого клевера с хорошо облиственными вегетативными побегами.

Қоличествєнный учет микрофлоры проводился ежемесячно, начиная с апреля и кончая сентябрем. Пробы для анализа брались на одних и тех же площадках каждого участка. Средняя проба состояла из пяти тщательно перемешанных индивидуальных проб, взятых в разных точках исследуемого участка на глубину $6-8$ см. Методом предельных разведений, с последующим посевом на соответствующие элективные среды, учитывались следующие группы микроорганизмов: гнилостные, аэробные целлюлозные, нитрифицирующие, денитрифицирующие бактерии, клостридиум (Clostridium Pasteurianum), азотобактер, актиномицеты. и грибы.

Проведенные анализы показали, что содержание важнейших групп микроорганизмов, участвующих в прєвращении питательных веществ, значительно больше в почвах культурных пастбищ, чем в почве луга.

Особенно велико отличие в развитии гнилостных, нитрифицирующих, денитрифицирующих и целлюлозных бактерий в почве культурного пастбища и естественного сенокоса в Куузику. Например, численность нитрифицирующих бактерий в почве пастбища на протяжении всєго вегетационного периода в десятки раз превышала их количество в почве сенокоса. Содержание аэробных целлюлозных бактерий в почве пастбища было больше в 3-4 раза. Различие наблюдалось не только в количественном содержании, но и в интенсивности накопления нитратов и разло-

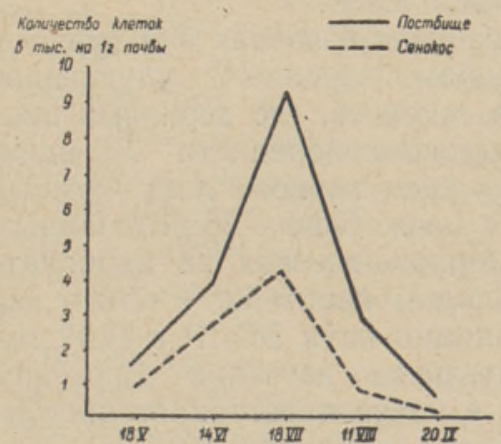

Рис. 1. Динамика развития аэробных целлюлозных бактерий в почве культурных пастбищ и сенокоса. Опыт в Куузику.

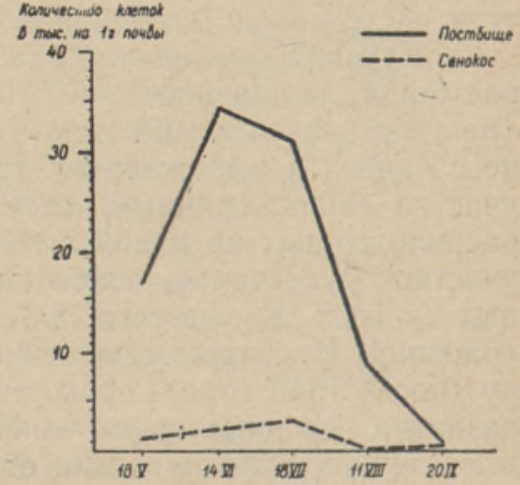

Рис. 2. Динамика развития нитрифицирующих бактерий в почве культурных пастбищ и сенокоса. Опыт в Куузику. 
жения целлюлозы. Разная интенсивность аэробного разложения целлюлозы была обусловлена различным составом целлюлозоразлагающих микроорганизмов. Если в почве культурного пастбища преобладала Cytophoga Hutchinsoni, то в пробах почвы с сенокоса разложение клетчатки происходило за счет деятельности менеє активных микробов из рода Cellvibrio, а также за счет плесеней и актиномицетов. Микробиологические процессы в почвах культурных пастбищ других исследованных участков, как длительного использования (в Йыгева), так и сравнительно молодых (Куузику), протекают значительно интенсивнєе, чем в почвах лугов, даже при совершенно одинаковых условиях удобрения (рис. 1 и 2). Сопоставляя данные, полученные по динамике микрофлоры в почве культурных пастбищ и в почве полевых участков, можно сделать заключение о,высокой биологической активности пастбищных почв, поскольку ни по количеству микроорганизмов, ни по активности основных микробиологических процєссов почвы пастбищ не уступают высокоплодородным полевым почвам (табл. 1).

Таблица 1

Динамика развития микрофлоры в почвах культурных пастбищ, культурного сенокоса и поля в Иыгева

\begin{tabular}{|c|c|c|c|c|c|c|c|}
\hline \multirow[b]{2}{*}{$\begin{array}{c}\text { Дата } \\
\text { анализа }\end{array}$} & \multirow{2}{*}{$\begin{array}{c}\text { Почвен- } \\
\text { ная } \\
\text { разность }\end{array}$} & \multirow[b]{2}{*}{ Угодия } & \multicolumn{5}{|c|}{$\begin{array}{c}\text { Количество микроорганизмов в тыс. } \\
\text { на } 1 \text { г абсолютно сухой почвы }\end{array}$} \\
\hline & & & $\begin{array}{c}\text { Аммони- } \\
\text { фицирую- } \\
\text { щне }\end{array}$ & $\begin{array}{l}\text { Целлю- } \\
\text { лозные }\end{array}$ & $\begin{array}{c}\text { Нитри- } \\
\text { фици- } \\
\text { рующие }\end{array}$ & $\begin{array}{c}\text { Денит- } \\
\text { рифици- } \\
\text { рующиє }\end{array}$ & $\begin{array}{l}\text { Клостри- } \\
\text { дий }\end{array}$ \\
\hline \multirow{2}{*}{$11 . \mathrm{V}$} & \multirow{12}{*}{$\begin{array}{l}\text { Почва дер- } \\
\text { ново-глеева- } \\
\text { тая, богатая } \\
\text { перегноем } \\
(\text { до } 15 \% \text { ) }\end{array}$} & пастбище & 7436,0 & 22,2 & 0,17 & 996,0 & 0,17 \\
\hline & & сенокос & 540,0 & 18,3 & 0,02 & 1,7 & 0,02 \\
\hline \multirow{2}{*}{$27 . \mathrm{V}$} & & пастбище & 5460,0 & 8,6 & 3,5 & 140,0 & 84,0 \\
\hline & & сенокос & 1278,0 & 6,3 & 0,1 & 16,6 & 1,0 \\
\hline \multirow{2}{*}{$22 . \mathrm{VI}$} & & пастбище & 1494,0 & 2,0 & 41,5 & 9960 & 1,0 \\
\hline & & сенокос & 2805,0 & 1,3 & 9,9 & 990 & 1,0 \\
\hline \multirow{2}{*}{ 18.VII } & & пастбище & 27300,0 & 54,6 & 682,5 & 27375,0 & 58,5 \\
\hline & & сенокос & 16000,0 & 15,0 & 12,5 & 125,0 & 3,0 \\
\hline \multirow{2}{*}{ 24.VIII } & & пастбище & 18000,0 & 116,0 & 100,0 & 1000,0 & 100,0 \\
\hline & & сенокос & 12800,0 & 81,2 & 100,0 & 1000,0 & 28,0 \\
\hline \multirow{2}{*}{ 21.IX } & & пастбище & 16800,0 & 107,0 & 420,0 & 3600,0 & 360,0 \\
\hline & & сенокос & 8000,0 & 96,0 & 11,5 & 1250,0 & 30,0 \\
\hline \multirow{2}{*}{$11 . \mathrm{V}$} & \multirow{10}{*}{$\begin{array}{l}\text { Почва дер- } \\
\text { ново-слабо- } \\
\text { подзолистая, } \\
\text { перегноя } 6 \%\end{array}$} & пастбище & 924,0 & 14,2 & 3,5 & 350,0 & 0,08 \\
\hline & & поле & 1786,0 & 2,2 & 3,9 & 385,0 & 0,09 \\
\hline \multirow{2}{*}{$27 . \mathrm{V}$} & & пастбище & 1570,0 & 29,5 & 3,9 & 157,0 & 39,00 \\
\hline & & поле & 3894,0 & 0,5 & 2,9 & 11,8 & 0,10 \\
\hline \multirow{2}{*}{ 18.VII } & & пастбище & 5544,0 & 8,0 & 154,0 & 385,0 & 0,40 \\
\hline & & поле & 5610,0 & 17,2 & 115,5 & 412,0 & 0,02 \\
\hline \multirow{2}{*}{ 24.VIII } & & пастбище & 5428,0 & 14,8 & 73,8 & 177,0 & 17,7 \\
\hline & & поле & 2152,0 & 16,0 & 17,2 & 24,0 & 3,10 \\
\hline \multirow{2}{*}{ 21.IX } & & пастбище & 3277,0 & 8,4 & 79,1 & 2825,0 & 2,30 \\
\hline & & поле & 1033,0 & 7,1 & 11,3 & 315,0 & 0,80 \\
\hline
\end{tabular}


Более интенсивное развитие микрофлоры в почвах культурных пастбищ по сравнению с сенокосом обнаруживается уже ранней весной, что соответствует также более быстрому оживлению травостоя на культурном пастбище. Так, например, численность нитрифицирующих бактерий, хорошее развитие которых принято считать показателем окультуренности и плодородия почвы, в почве культурного пастбища в Йыгева в начале мая в 10 раз превышало количество их в почве сенокоса. Такое превосходство нитрифицирующих бактерий в почвах пастбищ характерно для всех исследованных участков в тєчение всего вегетационного периода. Аналогичное преобладание численности в почвах пастбищ отмечено и для гнилостных, целлюлозных и денитрифицирующих бактерий, а также для клостридиума и актиномицетов. Различий в содержании грибов в почве пастбища и луга не наблюдалось. Исключение составляют только участки в Куузику, где в почве єстественного луга их было несколько больше, чем в почве культурного пастбища.

Поскольку исследованные участки в Йгева и Куузику имели некоторые отличия в характере травостоя, обусловленные различной длительностыю использования и разными почвами, отличался и количественный состав микрофлоры. В почвах культурных пастбищ Куузику количество микроорганизмов основных физиологических групп было значительно мєныше, чем в Иыгева, что, повидимому, объясняется меньшим содержанием перегноя и общей бедностью почв Куузику питательными веществами.

Сопоставляя данные по развитию микроорганизмов в почвах пастбищ и динамику отрастания травы на них, можно отметить, что в период максимального отрастания травы, когда растения продуцируют наибольшее количество корневых выделений, наиболее интєнсивно развиваются и основные группы микроорганизмов, (Красильников, 1934 и Федоров и Непомилуев, 1954). Усиление развития группы гнилостных и целлюлозных бактерий, а также актиномицетов во вторую половину лета, повидимому, объясняется отмиранием части побегов и их корнєвых систем в летне-осенний период (Смелов, 1947; Чепикова, 1942).

Исследования, проведенныє в 1953-1954 годах почвенной лабораторией Института растениеводства Академии наук Эстонской ССР (Г. А. Шабалина) показали, что органическое вещество в почвах культурных пастбищ не накапливается мертвым запасом. Указанное обстоятельство объясняется тем, что под влиянием аэробных микробиологических процєссов в верхнем дерновом слое пастбищной почвы происходит быстрая и более полная минерализация органического вещества.

Вследствие более высокой, чем на сенокосе, биологической активности верхнего слоя пастбищных почв, где расположена основная масса корней, а также влияния экскрєментов, оставленных животными, урожаи культурных пастбищ значительно выше, чем на сенокосе. Особенно большое отличие в активности микробиологических процессов наблюдалось в почве культурного пастбища и естественного сенокоса в Куузику. Большая разница была и в урожаях (на сенокосе урожай сена составлял около 1000 кормовых єдиниц, на пастбище - 3780 кормовых единиц с 1 га). Еще более показательно сравнение урожаев культурных пастбищ и сенокосов в Иыгева и Куузику, где почва и система удобрений на пастбище и луговом участке были одинаковы, только характер использования был разный. Урожай травы на пастбище в Йгева был вдвое больше, чем на сенокосе (2000 корм. ед. на сенокосе и 4260 корм. ед. на пастбище с 1 га), в Куузику в 1954 году на 70\% (1220 корм. ед. на сенокосе, 2060 корм. ед. на пастбище с 1 га) и в 1955 году на $50 \%$ выше урожая сенокоса (2040 корм. ед. на сенокосє и 3020 корм. ед. на пастбище с 1 га). 
Кроме проведенных в Иыгева анализов микрофлоры в почве культурного пастбища длительного использования (33 года), которые показали, что ни по количеству микроорганизмов, ни по интенсивности микробиологической деятельности почва пастбища не уступает окультуренной почве хорошо удобренного поля, в 1953 и 1954 годах на Вяндраской опытной станции Института животноводства и ветєринарии Академии наук Эстонской ССР проводились дополнительно сравнительные микробиологические исследования микрофлоры почв культурных пастбищ различной длительности использования.

Полученные в ходе исследований данные о развитии микрофлоры в почве загонов пастбищ длительного (20-30 летнего) использования и заложенных недавно (в 1950 году) показали отсутствие затухания микробиологической активности в почвах старых загонов по сравнению с молодыми. Нет больших отличий также в урожаях, полученных с участков различного возраста. Наибольший урожай (3357 корм. ед.) был в 1954 году получен на самом старом из сравниваемых загонов (31 год использования). Сопоставляя микробиологическую активность, урожаи и характер удобрения на загонах пастбищ различной продолжительности использования, можно сделать вывод, что интенсивность развития микрофлоры и продуктивность травостоя зависят не от длительности использования, а от ухода и системы удобрения, важное место в которой занимают органические удобрєния.

\section{Влияние органических удобрений на развитие почвенной микрофлоры культурных пастбищ}

В системе удобрения культурных пастбищ особенно важное значение имеют органические удобрения. Их роль не ограничивается обогащєнием почвы питательными веществами и улучшением ее физико-химических свойств. Органические удобрения повышают биогенность почвы вследствие обогащєния ее микроорганизмами и улучшения условий их питания, что в свою очередь повышает эффективность минеральных удобрений, мобилизуя и вовлекая в биологический оборот труднодоступные растениям запасы минеральных веществ в почве. Все это вместе взятое увеличиваєт продуктивность травостоя.

Для выяснения влияния обогащенных фосффором и калием торфонавозных компостов на развитие микрофлоры почв пастбищ в 1952-1954 годах проводились микробиологические исследования на культурных пастбищах экспериментальных баз Института животноводства и ветеринарии, Института растениеводства Академии наук ЭССР и Йгеваской Государственной селекционной станции. ${ }^{*}$ Основные опыты проводились по схеме: 1) контроль - без удобрения, 2) ежегодно 5 т обогащенного компоста на 1 га, 3) 10 т компоста на 1 га с перерывом в год, 4) 15 т компоста с перерывом в 2 года.

Кроме анализа микрофлоры в перечисленных выше опытах с компостами, автор в течение всего вегетационного периода изучал сравнительное действие органических и минеральных удобрений на микрофлору культурных пастбищ.

Анализы микрофлоры торфонавозных компостов, примененных в опытах, показали высокое содержание в них аммонифицирующих, нитрифицирующих и целлюлозных бактерий.

Проведенными исследованиями установлено, что органические удобрєния резко стимулируют микробиологические процессы в почвах паст$\ni$ СCP, 


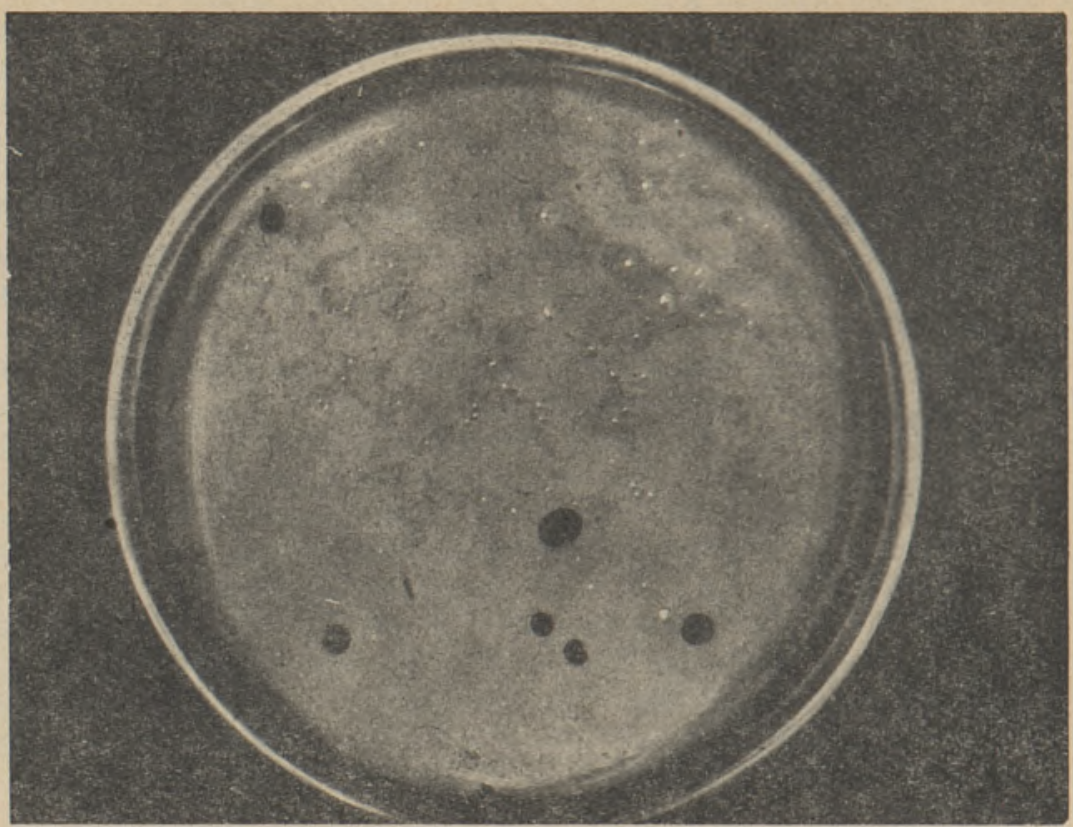

Рис. 3. Колонии нитрификаторов на водном агаре с аммонийномагниевой солью. Разведение $1: 10$. Опыт в Йгева. Контроль без компоста.

бищ. В удобренных компостом почвах значительно увеличивается количество и активность аммонифицирующих, нитрифицирующих, денитрифицирующих и целлюлозных бактерий, имеющих большое значение в повышении плодородия почвы. На группу гнилостных бактерий компост оказал наиболее сильное влияние во вторую половину лета, когда по удобренному фону в почвє накапливается бо́льшее количество корневых остатков. (Цивенко, 1953; Бронзова, 1940.) В отличие от развития гнилостных микробов, нитрифицирующие бактерии в почве удобренных компостом делянок уже ранней весной развивались значительно интенсивнее, чем в почве контрольных делянок (рис. 3 и 4). Повидимому, это явление можно объяснить способностью нитрифицирующих бактєрий использовать в период малой активности аммонификаторов в качестве энергетического материала поглощенный почвой аммиак (Логвинова, 1933; Allison и др., 1953).

Наибольшего развития нитрифицирующие бактерии достигают в июле и августе. В этот период абсолютное количество нитрификаторов на удобренных делянках по сравнению с неудобрєнными было наиболее высоким. Удобрение компостом не только увеличило количественное содержание нитрифицирующих бактерий, но, как показали анализы содержания нитратов в почвах, повысило также и активность их. Особенно большое отличие в активности нитрифицирующих бактерий наблюдалось в вєсенний период.

Более сильное влияние компоста на развитие нитрификаторов по сравнению с аммонифицирующими бактериями обусловлено, повидимому, бо́льшей требовательностью нитрификаторов к условиям среды и бо́льшей их отзывчивостью на улучшение этих условий.

Содержание дєнитрифицирующих бактерий под влиянием компостов возрастает. Более богатые нитрифицирующими бактериями почвы богаче 


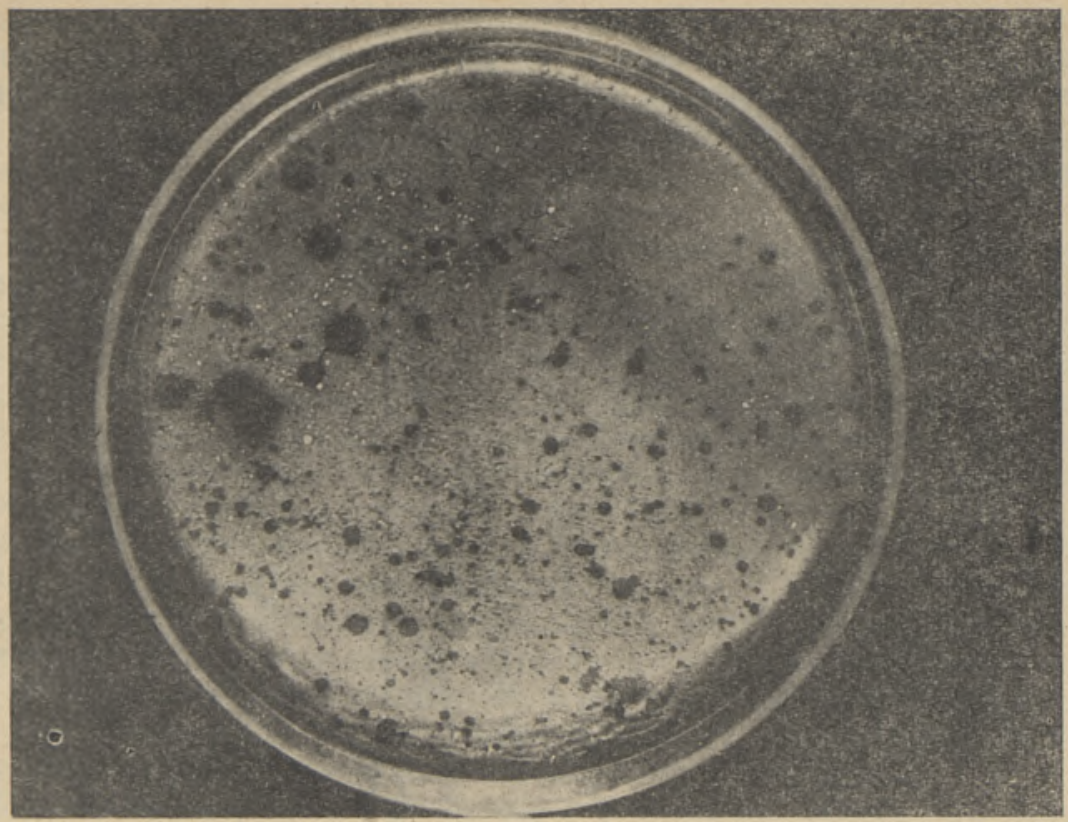

Рис. 4. Колонии нитрификаторов. Разведение 1:10. Опыт в Иыгева. 15 т компоста на 1 га.

и денитрификаторами. Однако четкой корреляции в динамике развития, нитрифицирующих и денитрифицирующих бактерий не установлено. Влечет ли увеличениє числа денитрифицирующих бактерий за собой увеличение потерь азота из почвы - это зависит, как известно, от целого ряда условий. В нормальных условиях увлажнения и хорошей аэрации почвы этих потерь может и не быть. Существовавшее до сих пор в науке представление о роли дєнитрифицирующих бактерий в превращениях азотсодержащих веществ в почвах в настоящее время пересматривается. Имеются данные о тесной сопряженности процесса нитрификации и денитрификации и о богатстве плодородных почв денитрифицируюшими бактериями. (Бєрезова и Бородулина, 1952; Корсакова, 1953, 1930; H. Barjac, 1954).

В наших исследованиях интенсивное развитие денитрифицируюших бактерий, наряду с нитрификаторами было, как правило, показателем высокого плодородия почвы.

Не менее сильное влияние, чем на группу нитрифицирующих бактерий компост в почве пастбища оказываєт на развитие целлюлозных бактерий. Увеличение целлюлозных бактерий при внесении компостов объясняется прежде всего увеличением количества нитратов за счет внесения их с компостами и в результатє усиления развития нитрификаторов, а также вследствие увеличения под влиянием компостов количества корневых остатков. Динамика развития целлюлозных бактерий в почвах, удобренных компостом, очень сходна с динамикой развития гнилостных микроорганизмов (рис. 5).

Закономерных изменений в развитии клостридиума, актиномицетов и плесневых грибов под действиєм компостов проведенными исследованиями не установлено.

При осеннем внесении компоста на пастбище уже ранней весной сле- 
дующего года, когда микробиологические процессы еще подавлены, на удобрєнных компостом делянках отмечалось более интенсивное развитие микрофлоры, что очень важно, так как улучшение питания растений вообще и в особенности азотом в этот период значительно повышает урожай травы.

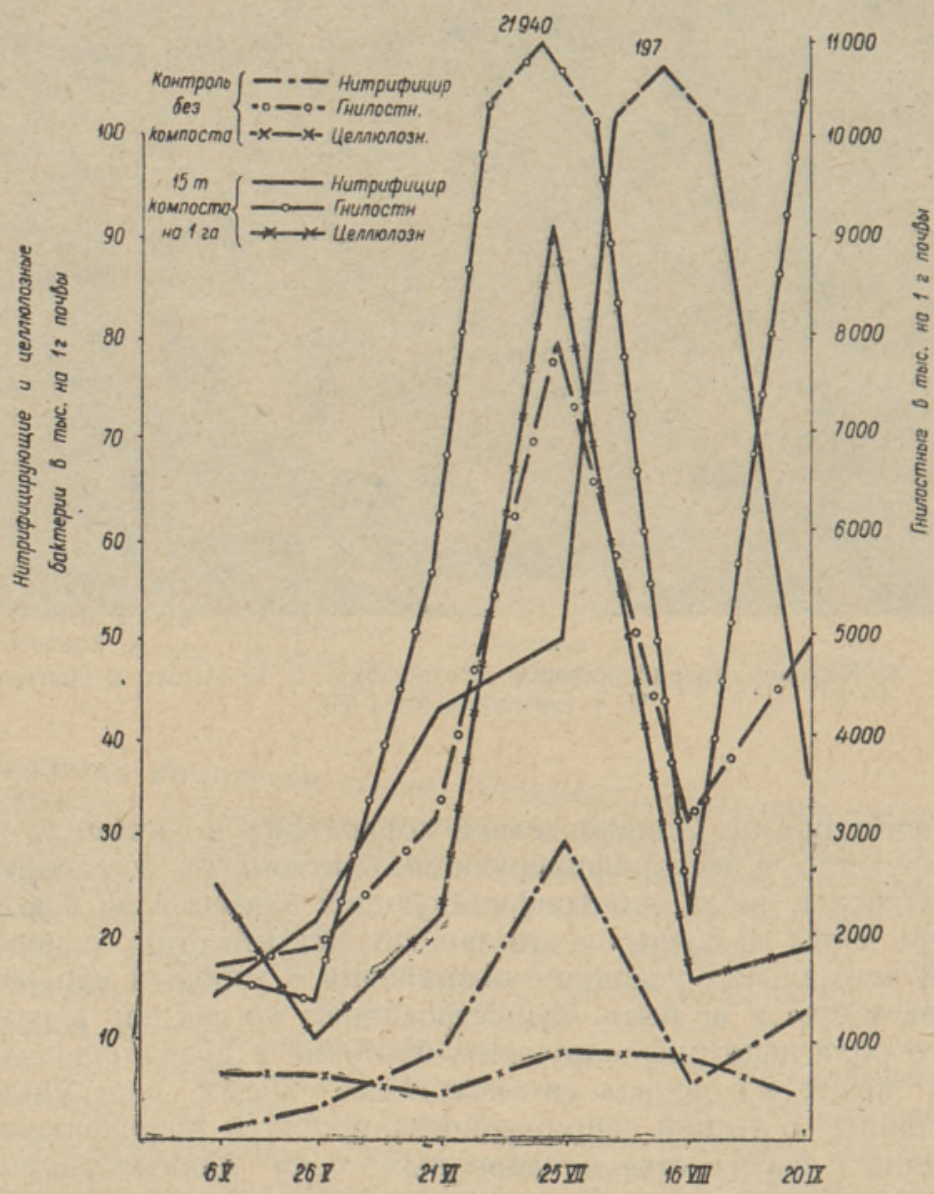

Рис, 5. Динамика развития микроорганизмов в почве культурного пастбища на удобренном и неудобренном участках. Опыт в Тяхтвере в 1954 г.

Увеличение количества микроорганизмов под влиянием компостов в летне-осенний период, т. е. в период максимального развития микробов, обусловлєно как прямым, так и косвенным влиянием компостов. Косвенное действие компостов заключается в увеличении корневой системы растений, часть которой, отмирая, дает больше пищи для бактерий и стимулирует их развитие. Интенсивная минерализация органических остатков улучшает питание растений в осенний период, что имеет важное значение в накоплении запасных питательных веществ для лучшей перезимовки трав и повышает урожай в следующем году. Между развитием микрофлоры и урожаями травы, за редкими исключениями, наблюдался параллелизм. Урожаи на культурных пастбищах в проведенных опытах повышались при внєсении компостов на $50-60$ и больше процентов.

Под влиянием малых доз компоста (5 т на 1 га) во всех опытах также наблюдалось повышение биогенности почвы и в соответствии с этим 
увеличивался урожай по сравнению с контролем. Следует отметить, однако, что увеличение количества микроорганизмов в этом случае не было столь постоянным, как при применении более высоких доз.

По фону органических удобрений в проведенных опытах повысилась эффективность минеральных, что, несомненно, обусловливается увеличением биологической активности почв.

Исследования микрофлоры почвы в опытах по сравнительному изучению действия минєральных и органических удобрений на продуктивность культурных пастбищ в Тяхтвере, Йгева и Куузику показали, что если внесенные органические удобрения значительно интенсифицируют микробиологические процессы, то минеральные удобрения (особєнно в кислой форме) при систематическом их применении без одновременного внесения органических удобрений не только не повышают, а, наоборот, умєньшают содержание полезных микробов.

В этих опытах урожай травы по фону органических удобрений превышал урожай по фону одних минеральных на 25-46\%, Лишь правильное сочетание органических и минеральных удобрений может обеспечить наилучшие условия для развития почвенных микроорганизмов и растений. Наивысшие урожаи травы на культурных пастбищах опытной станции Вяндра получают при регулярном (через $2-3$ года) внєсении органических удобрений вместе с минеральными удобрениями.

Динамика развития микрофлоры в течение вегетационного периода и действие удобрений на ее интєнсивность изучались на различных типах почв. Исследования показали, что тип почвы оказывает определенное влияние на характер микробиологических процессов. Абсолютное содержание отдельных физиологических групп микроорганизмов находится в прямой зависимости от количєства перегноя и влажности почвы.

В проведенных в 1952-1953 годах опытах с компостами была сделана попытка биологического обогащения почвы пастбища азотом, так как вопрос максимального удовлетворения потребностей растений в азоте является основным в решении проблемы получения высоких урожаев травы на культурных пастбищах. Компост перед внесєнием на пастбище зара жался азотобактером. Для заражения был взят местный штамм азотобактера. Обогащенный фосфором и калием компост вносился по фону сланцевой золы и без известкования.

Как показали микробиологические анализы, азотобактер в почвах пастбищ не приживается. Наряду с опытами на пастбище (четыре опыта в течение двух лет) ставился вегетационный опыт, в ходе которого исследовалась динамика развития азотобактера. во взятой с пастбища почве. Для опыта была взята почва без разрушения структуры и нарушения травостоя. Образцы почвы брались на глубину 15-17 см. В этом опыте наблюдалась та же картина быстрого вымирания внесенного с компостом азотобактера, как и в опытах на пастбище. В проведенных опытах исследовалось влияние на приживаемость азотобактера в почве пастбища факторов, которые прєдположительно могли ограничивать его развитие: вместе с компостом вносился фосфор и калий, почва нейтрализовалась известью, изменялись сроки внесения компоста с целью улучшения режима влажности (компост вносился ранней весной и летом после первого стравливания), с компостом вносились различные дозы азотобактера, компост заражали перєд самым внесением и за 2 недели до внесения. Во всех случаях азотобактер быстро исчезал. При анализе методом комочков азотобактером прорастало в лучших случаях $20-30 \%$ комочков почвы и только в первый месяц после внесения. Влияния азотобактера на урожай также не было отмечено.

Исследования наличия спонтанного азотобактера (методом комочков 
на твердой среде Эшби и методом почвенных пластинок по Виноградскому) в почвах культурных пастбищ в Куузику, Тяхтвере, Кыгева и Вяндра также подтвердили этот вывод. Из большого числа исследованных образцов почв, взятых с пастбищ (557 образцов), расположенных на различных типах почв, азотобактер был обнаружен только в очень-редких случаях и в очень малых количествах - прорастало $2-5 \%$ комочков, в то же время в почвах соседних с пастбищами полевых угодий азотобактер, как правило, имелся.

На безазотной среде Әшби из проб почвы с культурного пастбища в огромных количествах вырастали олигонитрофилы, число которых достигало нескольких миллионов на 1 г почвы. Среди них было очень много кислотообразователей.

Поскольку под влиянием пастбищного режима создается совершенно определенный, характерный для пастбища травостой, в почвє формируется также и специфичный микробный ценоз. В этом биоценозе азотобактер не находит для себя благоприятных условий, повидимому, в силу антагонистических отношений с ризосферными микроорганизмами, так как физико-химические условия в почвах культурных пастбищ складываются достаточно благоприятно для развития не менее требовательных к условиям среды, чем азотобактер, микроорганизмов.

Основным фиксатором азота на культурных пастбищах следует признать клубеньковые бактерии, развивающиеся на корнях широко распространенного в травостое пастбищ белого клевера. Для дальнейшего выяснения путєй воздействия на биологический круговорот азота в почвах культурных пастбищ необходимо, очевидно, провести глубокое изучение условий жизнедеятельности клубеньковых бактерий, а также исследовать роль олигонитрофилов и Clostridium Pasteurianum как фиксаторов азота в этих условиях.

Следует отметить, что особенности состава микрофлоры пастбишных почв и взаимоотношения отдельных физиологических групп в биоценозе этих почв пока еще совершенно не изучены. Дальнейшее детальное изучение микробиологических процессов в почвах культурных пастбищ и сенокосов позволит установить факторы, определяющие ход дернового процесса.

Углубленное изучение изменений в микрофлоре почвы культурного пастбища под влиянием удобрений представляет не только теоретический, но также значительный практический интерес. Выяснение условий, при которых внесенные удобрения могут дать наиболее выгодное, с точки зрения плодородия почвы, сочетание групп полезных микроорганизмов поможет найти пути наиболее эффективного использования органических и минеральных удобрений на культурном пастбище и в большей мере мобилизовать потенциальные природные запасы питательных веществ.

\section{Выводы}

1. Почвы культурных пастбищ отличаются высокой биологической активностью. По активности микробиологических процессов почвы культурных пастбищ, при условии правильного использования и регулярного удобрения, не уступают плодородным полевым почвам, значительно превосходя почвы естественных и культурных лугов.

2. В почвах культурных пастбищ длительного использования (2030 лет) основные физиологические группы микроорганизмов развиваются не менее активно, чем в почвах сравнительно недавно заложенных моло. дых пастбищ. 
3. Характерный для лугов дерновый процесс на культурных пастбищах даже при длительном использовании не развивается, что объясняется активной микробиологической деятельностью. Органическое вещество в почвах пастбищ не накапливается в больших количествах, урожаи травы не только не снижаются, но даже возрастают.

4. При сформировавшемся пастбищном биоценозе интенсивность микробиологических процессов и высота урожая зависят не от длительности использования пастбищ, а от регулярности применения удобрений и правильной загонной пастьбы. Особенно большое значение в системе удобрений культурных пастбищ имеют органические удобрения. Внесение органических удобрений резко стимулирует микробиологические процессы в почвах культурных пастбищ.

5. Повышение биологической активности пастбищных почв под влиянием органических удобрений коррелирует с увеличением продуктивности пастбищ. Обогащенные минеральными удобрениями торфонавозные компосты повышают урожай травы в 1,5 и больше раз.

6. Минеральные удобрения не оказывают стимулирующего действия на микрофлору почв пастбищ, а при длительном применении без внесения органических удобрений подавляют развитие микроорганизмов.

7. Внесение азотобактера вместе с компостом на пастбище не рационально, так как азотобактер в почвах пастбищ не находит благоприятных условий для своего развития и в биологическом обогащении этих почв азотом участия не принимает.

8. Дальнейшее комплексное изучение микробиологических процессов, круговорота органического вещества и динамики элементов питания растений в почвах культурных пастбищ и сенокосов поможет установить факторы, определяющие ход дернового процесса в условиях активного воздействия человека на плодородие лугов и пастбищ и регулировать этот процесс с целью получения высоких урожаев.

Институт растениеводства

Академии наук Эстонской ССР
Поступила в редакцию 16 I 1956

\section{ЛИТЕРАТУРА}

Берез ов а Е. Ф. и Бородулин а Ю. С., 1952. Влияние известкования на микрофлору почвы и корневой системы растения, Труды Института с.-х. микробиологии, x. XII.

Брон зова Г. Я., 1940. Влияние удобрений на развитие корневой системы луговых злаков и накопление в ней углеводов, Вестник кормодобывания, № 4.

Корсаков а М. П., 1953. Денитрифицирующие микроорганизмы, Микробиология, т. XXII, вып. 2.

Корс акова М. П., 1930. К методике определения денитрификации в почве, Труды Института с.-х. микробиологии, т. IV.

Кр асильников Н. А,, 1934. Влияние корневых выделений на развитие азотобактера и других почвенных микробов, Микробиология, т. III, вып. 3.

Л ог вин о ва З. Б., 1933. Торф как источник азота. Труды. НИУ, вып. 56.

Сме лов С. П., 1947. Биологические основы луговодства. Сельхозгиз.

Т оом ре Р. И., 1955. Опыт использования культурных пастбищ в ЭССР, Таллин.

$\Phi$ едоров М. В. и Не поми и у е в В. Ф., 1954. Основные формы ризосферных бактернй тимофеевки и изменение количества их клеток в ризосфере по фазам развития и годам жизни этого растения, Микробиология, т. XXIII, вып. 2.

Ц и в енко И. А., 1953. Влияние покровных культур и удобрений на накопление многолетними травами органического вещества в дерново-подзолистой почве, Почвоведение, № 1.

Че пикова А., 1942 . О времени отмирания корневой системы многолетних трав, Доклады ВАСХНИЛ, № 9-10.

All is on, F. E., D o et s ch, J., R o 11 e n, H., 1953. Availability of fixed ammonium in soil containing different clay minerals; Soil Sci. 75 , no. 5 .

B a r ja c, H., 1954. La microflore dénitrifiante sa présense normale dans le sol, Ann. Inst, Pasteur, 87. 


\section{MIKROBIOLOOGILISED PROTSESSID KULTUURKARJAMAADE MULDADES JA NENDE AKTIVISEERIMINE ORGAANILISTE VÄETISTE ANDMISEGA}

\section{T. VINOGRADOVA,}

põllumajandusteaduste kandidaat

Resümee

Karja suvise söötmise küsimus on Eesti oludes kõige edukamalt lahendatav pikaajaliselt kasutatavate kultuurkarjamaade rajamisega. Kultuurkarjamaade kõrget efektiivsust kinnitavad nii teaduslike uurimisasutuste poolt teostatud katsed kui ka vabariigi kolhooside ja sovhooside praktika. Vaatamata sellele on meie kultuurkarjamaade rajamine kuni viimase ajani toimunud väga aeglaselt, sest arvati, et pikaajaliselt kasutuselolevatel karjamaadel hakkab paratamatult toimuma kamardumise protsess, mille tagajärjel muldadesse koguneb surnud orgaanilist ainet, vaibuvad mikrobioloogilised protsessid, taimedele ei jätku mineraalaineid ja heinkate degenereerub. Tegelikult aga, nagu on näidanud kultuurkarjamaade kasutamise praktika meil ja välismail, lannavad nad heinaliikide õige valiku, öige karjatamisviisi ja süstemaatilise väetamise juures kümnete aastate kestel rikkalikku saaki.

Kultuurkarjamaade ratsionaalse kasutamise küsimuste lahendamisel ja nende tootlikkuse tõstmisel omab olulist tähtsust nende muldades toimuvate mikrobioloogiliste protsesside tundmine.

Samal ajal on aga väga vähe uuritud orgaaniliste ainete sünteesi ja lagunemise tingimusi rohumaade muldades. Peaaegu täiesti puuduvad tööd, mis oleksid pühendatud neis muldades leiduvate toitainete muutumise aluseks olevate mikrobioloogiliste protsesside uurimisele. Vähe on uuritud ka karjamaade väetamis- ja kasutusviiside mõju mikrobioloogiliste protsesside kulgemisele muldades.

Käesoleva töö eesmärgiks on kultuurkarjamaade muldades toimuvate mikrobioloogiliste protsesside uurimine ning nende võrdlemine niidu ja põllu muldades esinevate protsessidega selleks, et välja selgitada kamardumise protsessi erinevalt kulgemise bioloogilised alused nendes muldades. Sel eesmärgil uuriti mitmesugustel mullastikutüüpidel asuvaid karjamaid, millede vanus ja väetamisviisid olid erinevad.

Uurimistöö teiseks ülesandeks oli orgaaniliste väetiste mõju selgitamine kultuurkarjamaade tootlikkuse tõstmisel. Samal ajal uuriti ka orgaaniliste väetiste mõju nende muldade mikrofloora arenemisele.

Uurimistööd sooritati kolme aasta kestel (1951 - 1954) Eesti NSV Teaduste Akadeemia Taimekasvatuse Instituudi ning Loomakasvatuse ja Veterinaaria Instituudi katsebaaside kultuurkarjamaadel ning Jõgeva Riiklikus Sordiaretusjaamas.

Uurimistöö tulemused:

1. Kultuurkarjamaade mullad paistavad silma kõrge bioloogilise -aktiivsuse poolest.

Oige kasutamise ja korrapärase väetamise puhul ei jää kultuurkarjamaa muldades toimuvate mikrobioloogiliste protsesside aktiivsus maha viljakates põllumuldades toimuvate protsesside aktiivsusest ning nad ületavad märgatavalt nende protsesside aktiivsuse looduslike ja kultuurniitude muldades.

2. Pikaajalisel (20-30 alastat) kasutamisel olnud kultuurkarjamaade muldades arenevad mikroorganismide põhilised füsioloogilised grupid niisama aktiivselt kui noorte, alles hiljuti rajatud karjamaade muldades. 
3. Aktiivse mikrobioloogilise tegevuse tõttu ei arene kultuurkarjamaadel ka nende pikaajalisel kasutamisel niitudele iseloomulik kamardumise protsess. Siia ei kogune orgaanilist ainet suurtes kogustes ja saak ei lange, vaid koguni tõuseb.

4. Biotsönooside kujunemisel karjamaal sõltuvad mikrobioloogiliste protsesside intensiivsus ja heinasaak mitte karjamaa kasutamisaja kestusest, vaid väetamise regulaarsusest. Suur tähtsus kultuurkarjamaade väetamise süsteemis on orgaanilistel väetistel.

5. Orgaaniliste väetiste andmine stimuleerib järsult mikrobioloogilisi protsesse kultuurkarjamaade muldades.

6. Karjamaade muldade bioloogilise aktiivsuse tõusuga orgaanilise väetise mõjul kaasneb karjamaade produktiivsuse tõus. Mineraalväetistega rikastatud turvas-sõnnikkompostid tõstavad saaki 1,5 ja enam korda.

7. Mineraalväetised ei avalda stimuleerivat toimet karjamaade muldade mikrofloorale. Nende kestval kasutamisel ilma orgaaniliste väetisteta pidurdavad nad mikroorganismide arenemist.

8. Karjamaale azotobakterite andmine koos kompostiga pole ratsionaalne, sest azotobakterid ei leia karjamaa muldades oma arenemiseks soodsaid tingimusi ning nad ei võta osa nende muldade bioloogilisest rikastamisest lämmastikuga.

9. Rohumaade muldades toimuvate mikrobioloogiliste protsesside ja orgaanilise aine ringluse ning taimede toitainete elementide dünaamika edasine kompleksne uurimine aitab selgitada tegureid, mis määravad kamardumise protsessi käigu, ning võimaldab inimestel reguleerida seda protsessi kõrgete saakide saamise eesmärgil.

Eesti NSV Teaduste Akadeemia

Taimekasvatuse Instituut
Saabus toimetusse

16. I 1956

\title{
DIE MIKROBIOLOGISCHEN PROZESSE IM BODEN VON KULTUR- WEIDELAND UND DEREN AKTIVIERUNG DURCH ZUFUHRUNG ORGANISCHER DUNGMITTEL
}

\author{
T. WINOGRADOWA
}

\section{Zusammenfassung}

Zwecks Feststellung der biologischen Ursachen, welche den abweichenden Verlauf der Rasenbildung auf Wiesen und Weideplätzen beeinflussen, wurden vergleichende Untersuchungen der im Boden von Kulturweideplätzen, Wiesen und Feldern vor sich gehenden mikrobiologischen Prozesse angestellt. Die Untersuchungen erstreckten sich auf Weideland von verschiedener Bodenbeschaffenheit, verschiedener Exploitationsdatier und abweichenden Düngbedingungen.

Eine weitere Aufgabe der Untersuchungen bestand in der Erforschung der Bedeutung organischer Düngmittel für die Erhöhung der Ertragsfähigkeit von Kulturweideland verschiedener Bodenbeschaffenheit, bei gleichzeitiger Erforschung des Einflusses organischer Düngstoffe auf die mikrobiologischen Vorgänge in diesen Bodenarten. 
Das Ergebnis der Untersuchungen:

1. Die Bodenarten der Kulturweideplätze zeichnen sich durch hohe biologische Aktivität aus. Bei richtiger Nutzung und regelmässiger Düngung stehen die Kulturweiden in der Aktivität der mikrobiologischen Prozesse des Bodens keinesfalls dem fruchtbaren Feldboden nach, und übertreffen in dieser Beziehung um ein bedeutendes die Bodenarten der natürlichen Wiesen, wie auch der Kulturwiesen.

2. Im Boden der Kulturweideplätze langjähriger Nutzung (20-30 Jahre) entwickeln sich die wichtigsten physikalischen Gruppen der Mikroorganismen nicht weniger aktiv, als im Boden der verhältnismässig seit kurzem angelegten, jungen Weideplätze.

3. Der für Wiesen charakteristische Prozess der Rasenbildung findet, dank der aktiven mikrobiologischen Tätigkeit, keine Entwickelungsmöglichkeiten auf Kulturweideplätzen, selbst bei lange andauernder Nutzung der letzteren. In den Bodenarten der Kulturweideplätze findet keine Ansammlung grösserer Mengen organischen Stoffs statt, der Grasertrag zeigt keinen Rückgang, sondern nimmt, im Gegenteil, noch zu.

4. Bei der sich herausgebildenden Weidebiozönose hängt die Intensität der mikrobiologischen Prozesse und die Höhe der Ernteerträge nicht von der Nutzungsdauer der Weideplätze ab, sondern von einer regelmässigen Düngung und einem richtigen Weidesystem. Eine grosse Bedeutung im Düngungssystem haben die organischen Düngstoffe.

5. Die Zuführung organischer Düngmittel stimuliert wesentlich die mikrobiologischen Prozesse im Boden des Kulturweidelandes.

6. Die durch die Wirkung der organischen Düngstoffe bedingte Erhöhung der biologischen Aktivität des Bodens der Weideländer korreliert mit der Erhöhung der Produktivität der Weideplätze. Die durch mineralische Düngstoffe bereicherten Torf-Mist-Komposte erhöhen den Grasertrag ums anderthalbfache und mehr.

7. Der Mineraldünger hat keinerlei stimulierenden Einfluss auf die Mikroflora des Bodens der Weideländer; bei lange andauernder Verwendung desselben ohne Zuführung organischer Düngmittel, unterdrückt er die Entwickelung von Mikroorganismen und im Zusammenhang damit kommt die Wirksamkeit des Mineraldüngers nicht zu ihrer vollen Geltung.

8. Eine gemeinsame Zuführung von Azotobacter-Kultur und Komposi ist nicht rationell, da die Stickstoffbakterien in Böden der Weideländer keine günstigen Bedingungen vorfinden und an Bereicherung der Böden nit Stickstoff keinen Anteil nehmen.

9. Weitere komplexe Erforschung der mikrobiologischen Prozesse im Boden der Kulturweideländer und Wiesen, sowie des Kreislaufs der organischen Stoffe und der Dynamik der Elemente der Pflanzennährstoffe wird zur Feststellung derjenigen Faktoren beitragen, die für den Prozess der Rasenbildung massgebend sind, sowie die Möglichkeit schaffen, durch aktives Eingreifen des Menschen die Ertragsfähigkeit der Weideländer und Wiesen zu erhöhen.

Institut für Pflanzenbau

der Akademie der Wissenschaften der Estnischen SSR
Eingegangen am 16. Jan. 1956 